\title{
High prevalence of RET proto-oncogene activation (RET/PTC) in papillary thyroid carcinomas
}

\author{
King Yin Lam, Chung Yau Lo ${ }^{1}$ and Po Sing Leung ${ }^{2}$
}

Division of Pathology, School of Medicine, James Cook University, Townsville, Queensland, Australia, ${ }^{1}$ Department of Surgery, University of Hong Kong, Hong Kong and ${ }^{2}$ Department of Physiology, Chinese University of Hong Kong, Hong Kong

(Correspondence should be addressed to Alfred K Y Lam, Division of Pathology, James Cook University, Townsville, Queensland 4811, Australia; Email: Alfred.Lam@jcu.edu.au)

\begin{abstract}
Objective: The activation of RET proto-oncogene, through different types of chromosomal translocation and inversion, is unique to papillary thyroid carcinomas (PTC) and its frequency is variable in different populations. The aim of this study was to investigate the frequency and types of PTC genetic rearrangements in papillary carcinoma in a population of Hong Kong Chinese.

Methods: The presence of RET/PTC1, RET/PTC2 and RET/PTC3 activation was analyzed by RT-PCR in twenty PTC from adult patients (age range 24-63 years), one PTC from a 12-year-old boy and anaplastic carcinomas in two adult patients.

Results: RET/PTC3 was the only activation of RET proto-oncogene identified in the samples. Seventeen PTC from adult patients (85\%t) were positive for RET/PTC3. RET/PTC3 was also identified in PTC from the child and one of the two patients with anaplastic thyroid carcinoma.

Conclusions: The prevalence of RET/PTC activation in PTC is high and RET/PTC3 is the only type of activation identified in Hong Kong Chinese and is an important genetic event underlying the development of PTC in the population.
\end{abstract}

European Journal of Endocrinology 147 741-745

\section{Introduction}

Papillary thyroid carcinoma (PTC) is the most common type of thyroid malignancy (1). The tumor is associated with somatic mutations of RET proto-oncogene, which is activated by gene rearrangements (2). The rearranged proto-oncogene, PTC oncogene (RET/PTC) is the product of the fusion of the tyrosine-kinase domain of the proto-RET to other genes. The three most common variants are RET/PTC1, RET/PTC2 and RET/PTC3 (2). In RET/PTC1 and RET/PTC3 the tyrosine-kinase domain fuses with the genes $\mathrm{H} 4$ and ELE1 respectively. RET/PTC2 arises from chromosome 10/17 translocation. There are also a number of RET/PTC activation variants, RET/PTC4, RET/PTC5, RET/PTC6, RET/PTC7, RET/PTC8, etc. (3).

The frequency of RET/PTC activation varies widely between reported series from different ethnic groups (4). In Hong Kong, despite the high incidence of thyroid cancers, there are no data on the characteristics of RET activation in thyroid cancers. In the present report, we examine the incidence and type of RET/PTC activation in thyroid cancers obtained from a population of Chinese from Hong Kong.

\section{Subjects and methods}

\section{Subjects}

Tissue samples were obtained prospectively from Chinese patients with thyroidectomy for confirmed thyroid cancer performed between 1996 and 2000 at Queen Mary Hospital, Hong Kong. Twenty-three patients with primary thyroid cancer were selected for the study (Table 1). None of the patients had a previous history of radiation exposure. The thyroid cancers comprised twenty-one PTC and two anaplastic carcinomas of the thyroid gland. The size and location of the thyroid cancer were examined at the time of surgery. Representative blocks were snap frozen in liquid nitrogen immediately after removal and stored in a $-70^{\circ}$ refrigerator. Other sections of the thyroid gland were sectioned serially and embedded for histological examination. The histology was determined according to standard criteria (4). Patients with papillary microcarcinoma were excluded from the study. The thyroid cancers that were kept frozen were confirmed to be free of normal tissue on histological examination. The staging was done according to the classification of the American Joint Committee on Cancer (5). The clinical data 
Table 1 Clinicopathological features and the presence of RET/PTC3 rearrangement in patients with thyroid cancer.

\begin{tabular}{|c|c|c|c|c|c|}
\hline Patient & Sex/age & Size site $(\mathrm{cm})$ & Stage grouping* & RET/PTC3 & $\begin{array}{l}\text { Follow-up/(months) } \\
\text { and remarks }\end{array}$ \\
\hline PCA1 & $\mathrm{F} / 27$ & 2.5 Right & T2N1M0, Stage 2 & Positive & 66 \\
\hline PCA2 & $\mathrm{F} / 69$ & 4.0 Left & T4N1M0, Stage 3 & Positive & 40 \\
\hline PCA3 & $\mathrm{F} / 46$ & 3.0 Right & T2NOM0, Stage 2 & Positive & 60 \\
\hline PCA4 & $\mathrm{F} / 25$ & 1.5 Right & T2NOMO, Stage 1 & Positive & 48 \\
\hline PCA5 & $\mathrm{M} / 48$ & 4.5 Right & T4N1M0, Stage 3 & Negative & 50 \\
\hline PCA6 & $\mathrm{M} / 69$ & 2.0 Right & T4NOM0, Stage 3 & Negative & 46 \\
\hline PCA7 & $\mathrm{F} / 79$ & 4.5 Left & T3NOM0, Stage 2 & Positive & 45 \\
\hline PCA8 & $\mathrm{M} / 45$ & 3.0 Left & T4N1M0, Stage 3 & Positive & 40 \\
\hline PCA9 & $F / 38$ & 1.5 Right & T2NOM0, Stage 1 & Positive & 38 \\
\hline PCA10 & M/65 & 5.0 Left & T4N1M0, Stage 3 & Positive & 36 \\
\hline PCA11 & $\mathrm{F} / 24$ & 2.5 Left & T4N1M0, Stage 1 & Positive & 35 \\
\hline PCA12 & $\mathrm{F} / 33$ & 2.0 Right & T4NOM0, Stage 1 & Positive & 26 \\
\hline PCA13 & $\mathrm{M} / 61$ & 5.0 Right & T4NOMO, Stage 3 & Positive & 25 \\
\hline PCA14 & $\mathrm{F} / 31$ & 2.0 Right & T4NOM0, Stage 1 & Positive & 25 \\
\hline PCA15 & $\mathrm{M} / 76$ & 4.0 Right & T4N1M0, Stage 3 & Positive & 25 , tall-cell variant \\
\hline PCA16 & $\mathrm{F} / 35$ & 3.0 Right & T2NOMO, Stage 1 & Positive & 9 \\
\hline PCA17 & $\mathrm{F} / 50$ & 5.0 Right & T4N1M0, Stage 3 & Positive & 9 \\
\hline PCA18 & $\mathrm{F} / 83$ & 2.5 Right & T4NOMO, Stage 3 & Positive & 9 \\
\hline PCA19 & $\mathrm{F} / 41$ & 1.3 Right & T2NOM0, Stage 1 & Negative & 8 \\
\hline PCA20 & $\mathrm{F} / 78$ & 4.0 Right & T4N1M0, Stage 3 & Positive & 7 \\
\hline PCA21 & $\mathrm{M} / 12$ & 2.0 Right & T2N1M0, Stage 1 & Positive & 21 , recurred at 9 months \\
\hline UC1 & $\mathrm{F} / 69$ & 5.0 Right & T4N1M0, Stage 4 & Negative & Died at 7 months \\
\hline UC2 & $\mathrm{F} / 82$ & 6.0 Right & T4N1M0, Stage 4 & Positive & Died at 10 months \\
\hline
\end{tabular}

*Tumor staging according to the American Joint Committee on Cancer (5). PCA, papillary carcinoma; UC, anaplastic carcinoma.

and follow-up information of these patients were also retrieved and analyzed.

\section{Methods}

The RET activation in the thyroid cancers was studied by reverse transcriptase-polymerase chain reaction (RT-PCR). Total RNA was isolated from the selected thyroid cancers using a Trizol isolation kit according to the instructions from the manufacturer (GIBCOBRL, Grand Island, NY, USA). The resultant pellet was then resuspended in water treated with diethylpyrocarbonate. The total RNA was studied by gel electrophoresis and quantified by spectrophotometry. The procedure for RT-PCR was modified as described in a previous study (6). Total RNA $(1-5 \mu \mathrm{g})$ was subjected to first strand cDNA synthesis using a system of oligo (dT) primers and Superscript II transcriptase (GIBCOBRL) in a final volume of $20 \mu \mathrm{l}$. After incubation at $42{ }^{\circ} \mathrm{C}$ for $1 \mathrm{~h}$, the reaction mixture was treated with RNase $\mathrm{H}$ before proceeding to PCR analysis.

PCR amplification was obtained in a final reaction volume of $100 \mu \mathrm{l}$. The reaction mixture was comprised of $10 \mu \mathrm{l} \mathrm{PCR}$ buffer $(10 \times), 200 \mathrm{mM}$ Tris-HCl $(\mathrm{pH}$ 8.4), $500 \mathrm{mM} \mathrm{KCl}, 3 \mu \mathrm{l} 50 \mathrm{mM} \mathrm{MgCl}_{2}, 2 \mu \mathrm{l}$ each of the sense and antisense primers $(10 \mu \mathrm{M}), 1 \mu \mathrm{l}$ Taq DNA polymerase $(1-5 \mathrm{U} / \mu \mathrm{l}), 2 \mu \mathrm{l} \mathrm{cDNA}$ and $80 \mu \mathrm{l}$ water. An expression study was performed using specific oligonucleotide primers for PTC1, PTC2 and PTC3 as employed by Viglietto et al. (7). The sequence of the forward primers used were: RET/PTC1: 5'-ATTGTCATCTCGCCGTTC-3'; RET/PTC2: 5'-TATCGCAGGAGAGACTGTGAT-3'; RET/PTC3: 5'-AAGCAAACCTGCCAGTGG-3'. The sequence of the reverse primer was $5^{\prime}$-TGCTTCAGGACGTTGAAC-3'. Human $\beta$-actin was used as a positive control for PCR reaction with a sequence of $5^{\prime}$-GGCTACAGCTTCACCACCA-3' as forward primer and 5'-ACGGATGTCCACGTCACAC-3' as reverse primer. The RNA was tested to be free of DNA contamination by RT-PCR without the addition of reverse transcriptase. The PCR conditions were 40 cycles of denaturing at $94^{\circ} \mathrm{C}$ for $1 \mathrm{~min}$, annealing at $60{ }^{\circ} \mathrm{C}$ for $1 \mathrm{~min}$ and elongating at $72^{\circ} \mathrm{C}$ for $2 \mathrm{~min}$. Lastly, the amplified mixture $(10 \mu \mathrm{l})$ was finally separated on $2 \%$ agarose gel electrophoresis and the amplified DNA bands were detected using ethidium bromide staining.

\section{Results}

Twenty-three patients with thyroid cancer were selected for the study (Table 1). None of the patients had a previous history of radiation exposure. The thyroid cancers comprised 21 PTC and two anaplastic carcinomas of the thyroid gland.

Apart from one PTC obtained from a 12-year-old boy, the other papillary carcinomas were seen in adults (14 women, 6 men) with a mean age of 51 years (range from 24 to 83 years). The average tumor size was 
$3.1 \mathrm{~cm}$ (range from 1.3 to $5 \mathrm{~cm}$ ). At the time of diagnosis, nine patients $(45 \%)$ had lymph node metastases and thirteen (65\%) had extra-thyroidal tumor invasion. A tall-cell variant of papillary carcinoma was detected in one patient. Over a median follow-up of 3 years (range from 7 to 66 months), all adult patients were alive without disease. The 12-year-old boy underwent excision of lymph node recurrence 9 months after the initial operation. He was free of disease at the date of the last follow-up. No death or local recurrence has occurred during the period of follow-up for these patients with PTC. Two women (69 and 82 years) suffered from anaplastic thyroid carcinomas and died 7 and 10 months respectively after the operation.

Among the twenty PTC from adult patients, seventeen were positive for RET/PTC3 activation (Fig. 1). They were negative for RET/PTC1 and RET/PTC2 activation. Negativity for RET/PTC activation occurred in two men and one woman. The presence of the RET/PTC activation showed no relation to the age of the patients, size of the thyroid tumors, location of the thyroid tumors, lymph node status or extent of the tumor. The papillary thyroid carcinoma from the child also showed positive RET/PTC3 activation.

One of the two patients with anaplastic carcinoma was positive for RET/PTC3 activation. On histological examination, the anaplastic carcinoma positive for RET/PTC3 activation showed a minor component of papillary carcinoma.

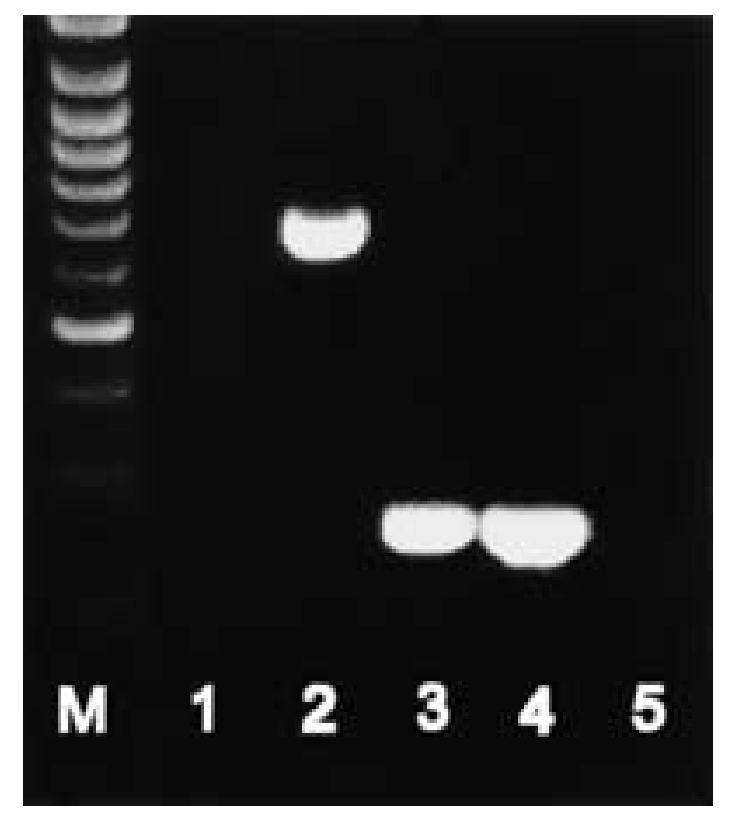

Figure $1 \mathrm{~A}$ representative image of gel electrophoresis from RTPCR analysis for RET activation. $\mathrm{M}=100$ bp DNA marker; 1 = normal thyroid tissue with no RET/PTC activation; 2 = papillary thyroid carcinoma with RET/PTC3 activation; $3=\beta$-actin expression in normal thyroid tissue; $4=\beta$-actin expression in thyroid carcinoma; $5=$ negative control without the addition of reverse transcriptase.

\section{Discussion}

RT-PCR is a widely accepted method for the detection of RET/PTC activation. The method is sensitive and allows the identification of different types of activation in PCA (Table 2).

Radiation-induced PTC is associated with a high incidence of RET/PTC activation. The average prevalence rate in PTC of patients affected by the Chernobyl nuclear plant fall-out in 1986 was 63\% (range 51$87 \%)(8-11)$. High prevalence rate $(84 \%)$ of RET/PTC was also detected in the patients with PTC who had a history of neck irradiation $(11,12)$.

Overall, areas exposed to radiation had a higher prevalence of RET/PTC activation in PTC compared with that in other areas. Patients with PTC from European countries (not directly affected by the Chernobyl accident) had an average of $19 \%$ (range $8-50 \%$ ) prevalence of RET/PTC activation (11-17). On the other hand, series from North America reported that approximately half (range $45-77 \%$ ) of the PTC had RET/PTC activation (8, 18-20). Chua et al. (21) also reported a high prevalence $(77 \%)$ of activation in PTC from Australia and New Caledonia. In these areas, ozone depletion has affected ambient radiation levels. This may explain the high incidence of RET/PTC activation.

The prevalence of RET/PTC activation in PTC has regional variations in Asia. In general, the prevalence reported is low in Korea $(0-13 \%)$ and Japan (25$36 \%)(16,22-24)$. On the other hand, the prevalence of RET/PTC activation seems to be high in Chinese populations. Lee et al. (25) reported a 55\% (6 out of 11) prevalence in Chinese patients in Taiwan. In the current series, we found that $85 \%$ (17 out of 20 ) of PTC in our Hong Kong Chinese adult patients had RET/PTC activation. The prevalence is as high as those reported in thyroid tumors from Australia and areas exposed to the Chernobyl accident. It is possible then, that over and above environmental influences and the difference in means of detection of RET/PTC activation, genetic factors may account for the different prevalence of RET/PTC in PTC.

Among the three types of RET/PTC activation, RET/PTC3 is the commonest type of activation noted in childhood thyroid cancers from areas exposed to the Chernobyl accident (8-11). In other populations, RET/PTC1 is the activation most often noted in thyroid PTC. Tumors with more than one type of RET/PTC activation are sometimes found in PTC reported from North America and Australia $(8,18-20)$. In nearly all series, RET/PTC2 activation was uncommon in PTC. However, Lee et al. (25) in Taiwan reported that the most common RET/PTC activation in thyroid PTC was RET/PTC2.

In our population, RET/PTC3 was the only type of RET/PTC activation identified in PTC. This finding is unusual in sporadic non-radiation-induced PTC. Nevertheless, Kitamura et al. (16) in Japan reported a similar 
Table 2 The different types of RET/PTC activation reported in human papillary thyroid carcinomas.

\begin{tabular}{|c|c|c|c|c|c|c|c|c|}
\hline $\begin{array}{l}\text { Reference } \\
\text { (year) }\end{array}$ & Place & RT & $\begin{array}{l}\text { No. positive/ } \\
\text { no. tested }\end{array}$ & $\begin{array}{l}\text { RET/ } \\
\text { PTC1 }\end{array}$ & $\begin{array}{l}\text { RET/ } \\
\text { PTC2 }\end{array}$ & $\begin{array}{l}\text { RET/ } \\
\text { PTC3 }\end{array}$ & Others & Remarks \\
\hline \multicolumn{9}{|c|}{ Region affected by Chernobyl accident } \\
\hline $8(1997)$ & Belarus & + & $33 / 38(87 \%)$ & 6 & 1 & 22 & 4 unknown & All children \\
\hline \multirow{2}{*}{$9(1999)$} & Belarus & + & $20 / 39(51 \%)$ & 9 & 0 & 11 & - & All children \\
\hline & Ukraine & + & $17 / 28(61 \%)$ & 5 & 0 & 12 & - & All children \\
\hline \multirow[t]{3}{*}{10 (1999) } & Belarus & & & & & & & \\
\hline & Children & + & $6 / 51(51 \%)$ & 12 & 0 & 13 & 1 novel & \\
\hline & Adult & + & $13 / 16(81 \%)$ & 11 & 0 & 2 & - & \\
\hline $12(2001)$ & Belarus & + & $19 / 25(76 \%)$ & 4 & - & 5 & $\begin{array}{l}6 \text { unknown } \\
2 \text { (PTC1 + PTC3) }\end{array}$ & All children \\
\hline \multicolumn{9}{|l|}{ North America } \\
\hline \multirow[t]{2}{*}{$18(1998)$} & Canada & - & $30 / 39(77 \%)$ & 12 & 3 & 6 & 9 multiple & All papillary microcarcinoma \\
\hline & & - & $21 / 45(47 \%)$ & 9 & 3 & 5 & 4 multiple & No papillary microcarcinoma \\
\hline 8 (1997) & USA & - & $12 / 23(52 \%)$ & 8 & 0 & 3 & 1 unknown & All children \\
\hline 19 (1998) & USA & - & $17 / 28(61 \%)$ & 10 & 1 & 0 & 6 (PTC1 + PTC3) & $\begin{array}{l}\text { Some may be from Hawaii or } \\
\text { Spain }\end{array}$ \\
\hline $20(2000)$ & USA & - & $14 / 32(44 \%)$ & 8 & 2 & 2 & 2 (PTC1 + PTC2) & $\begin{array}{l}\text { Child with history of RT } \\
\text { excluded }\end{array}$ \\
\hline \multicolumn{9}{|l|}{ Australia } \\
\hline \multirow[t]{2}{*}{$21(2000)$} & New Caledonia & - & $19 / 27(70 \%)$ & 8 & 0 & 3 & 8 multiple & $\begin{array}{l}1(\mathrm{PTC} 1+2), 4(\mathrm{PTC} 1+3), \\
2(\mathrm{PTC} 2+3), 1(\mathrm{PTC} 1+2+3)\end{array}$ \\
\hline & Australia & - & $17 / 20(85 \%)$ & 2 & 2 & 1 & 11 multiple & $\begin{array}{l}2(\mathrm{PTC} 1+2), 4(\mathrm{PTC} 1+3), \\
2(\mathrm{PTC} 2+3), 3(\mathrm{PTC} 1+2+3)\end{array}$ \\
\hline \multicolumn{9}{|l|}{ Western Europe } \\
\hline \multirow[t]{2}{*}{$11(1997)$} & France & + & $16 / 19(84 \%)$ & 12 & 0 & 2 & 2 (PTC1 + PTC3) & Patients treated with irradiation \\
\hline & France & - & $3 / 20(15 \%)$ & 1 & 0 & 1 & 1 uncharacterized & \\
\hline $13(1998)$ & Italy & - & $26 / 76(34 \%)$ & 13 & 2 & 11 & - & \\
\hline 14 (1998) & Sweden & - & $4 / 50(8 \%)$ & 4 & 0 & 0 & - & All adult patients \\
\hline 15 (1998) & Germany & - & 8/99 (8\%) & 7 & 0 & 1 & - & \\
\hline 16 (1999) & Germany & - & $3 / 16(19 \%)$ & 3 & 0 & 0 & - & \\
\hline 17 (2000) & Germany & - & $17 / 119(14 \%)$ & 11 & 1 & 3 & 2 uncharacterized & \\
\hline \multirow[t]{3}{*}{$12(2001)$} & Italy & & & & & & & \\
\hline & Children & - & $10 / 25(40 \%)$ & 5 & - & 4 & 1 unknown & \\
\hline & Adult & - & $11 / 22(50 \%)$ & 2 & - & 7 & $\begin{array}{l}1 \text { (PTC1 }+ \text { PTC3) } \\
1 \text { unknown }\end{array}$ & \\
\hline \multicolumn{9}{|c|}{ 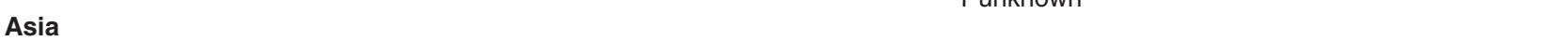 } \\
\hline 22 (1998) & Korea & - & $0 / 24(0 \%)$ & 0 & 0 & 0 & - & \\
\hline 23 (1999) & Korea & - & $4 / 31(13 \%)$ & 2 & 2 & 0 & - & \\
\hline \multirow[t]{3}{*}{24 (1998) } & Japan & & & & & & & \\
\hline & Children & - & $3 / 10(30 \%)$ & 2 & 0 & 1 & - & \\
\hline & Adult & - & $4 / 11(36 \%)$ & 3 & 0 & 1 & - & \\
\hline 16 (1999) & Japan & - & $10 / 40(25 \%)$ & 2 & 1 & 6 & 1 novel & \\
\hline 25 (1998) & Taiwan & - & $6 / 11(55 \%)$ & 2 & 3 & 1 & - & \\
\hline Present (2002) & Hong Kong & - & $17 / 20(85 \%)$ & 0 & 0 & 17 & - & $\begin{array}{l}\text { No papillary microcarcinoma, } \\
\text { All adult (a child was excluded) }\end{array}$ \\
\hline
\end{tabular}

RT, radiation exposure. In multiple series on the same group of patients, the one that is largest or that with information on different types of RET/PTC is listed.

finding of a high incidence of RET/PTC3 in non-radiation-related thyroid PTC. They found that $60 \%$ of the thyroid cancers had RET/PTC3 activation. The type of RET/PTC activation from PTC in Asian cities may be different from the Western populations and genetic differences between various populations may be responsible for such differences.

The presence of RET/PTC activation may have a prognostic role in PTC. In the present series, the prevalence of the RET/PTC activation was high and thus no significant correlation of the RET activation with the clinicopathological factors could be demonstrated.

The majority of anaplastic carcinomas arise from pre-existing well-differentiated thyroid carcinoma, such as PTC, rather than de novo. In fact, papillary carcinomas could be detected as a minor component in some cases of papillary thyroid carcinomas. La Perle et al. (26) demonstrated in mice that the lack of functional p53 in RET/PTC1-induced thyroid tumors promoted anaplasia and invasiveness of thyroid carcinoma. In fact, we had previously demonstrated that the p53 mutation was only present in anaplastic carcinomas but not in PTC or poorly differentiated thyroid carcinomas (27). In the present series, one anaplastic carcinoma was also positive for RET/PTC activation. In this case, the presence of a minor component of papillary carcinoma was also noted on histological examination. Thus, the RET/PTC activation in the 
anaplastic carcinoma may be attributed to the presence of the PTC in the vicinity of the anaplastic carcinoma. The other anaplastic carcinoma without this welldifferentiated thyroid carcinoma component did not reveal any RET/PTC activation. The findings are in agreement with the notion that RET/PTC is an early event but p53 mutation is a late event in the carcinogenesis of thyroid cancers.

In summary, the prevalence of RET/PTC activation is high and the type of activation is unique in PTC in Chinese populations. As suggested by the results of this study, RET activation may be an important genetic event underlying the development of papillary thyroid carcinomas in Hong Kong Chinese.

\section{References}

1 Lorentz TG, Lau PW, Lo CY, Law WL, Wan KY \& Lauder IJ. Multivariate analysis of risk factors influencing survival in 110 ethnic Chinese with papillary thyroid cancer. World Journal of Surgery $199418547-550$.

2 Pacini F, Elisei R, Romei C \& Pinchera A. RET proto-oncogene mutations in thyroid carcinomas: clinical relevance. Journal of Endocrinological Investigation 200023 328-338.

3 Kjellman P, Learoyd DL, Messina M, Weber G, Hoog A, Wallin G et al. Expression of the RET proto-oncogene in papillary thyroid carcinoma and its correlation with clinical outcome. British Journal of Surgery $2001 \mathbf{8 8} 557-563$.

4 Lam AK, Montone KT, Nolan KA \& Livolsi VA. Ret oncogene activation in papillary thyroid carcinoma: prevalence and implication on the histological parameters. Human Pathology 199829 $565-568$.

5 Hundahl SA, Cady B, Cunningham MP, Mazzaferri E, McKee RF, Rosai J et al. Initial results from a prospective cohort study of 5583 cases of thyroid carcinoma treated in the United States during 1996. US and German Thyroid Cancer Study Group. An American College of Surgeons Commission on Cancer Patient Care Evaluation study. Cancer 200089 202-217.

6 Leung PS, Chan WP \& Nobiling R. Regulated expression of pancreatic renin-angiotensin system in experimental pancreatitis. Molecular and Cellular Endocrinology 2000166 121-128.

7 Viglietto G, Chiappetta G, Martinez-Tello FJ, Fukunaga FH, Tallini G, Rigopoulou D et al. RET/PTC oncogene activation is an early event in thyroid carcinogenesis. Oncogene 199511 1207-1210.

8 Nikiforov YE, Rowland JM, Bove KE, Monforte-Munoz H \& Fagin JA. Distinct pattern of ret oncogene rearrangements in morphological variants of radiation-induced and sporadic thyroid papillary carcinomas in children. Cancer Research $1997 \mathbf{5 7}$ 1690-1694.

9 Thomas GA, Bunnell H, Cook HA, Williams ED, Nerovnya A, Cherstvoy ED et al. High prevalence of RET/PTC rearrangements in Ukrainian and Belarussian post-Chernobyl thyroid papillary carcinomas: a strong correlation between RET/PTC3 and the solid-follicular variant. Journal of Clinical Endocrinology and Metabolism 199984 4232-4238.

10 Smida J, Salassidis K, Hieber L, Zitzelsberger H, Kellerer AM, Demidchik EP et al. Distinct frequency of ret rearrangements in papillary thyroid carcinomas of children and adults from Belarus. International Journal of Cancer $19998032-38$.

11 Bounacer A, Wicker R, Caillou B, Cailleux AF, Sarasin A, Schlumberger $\mathrm{M}$ et al. High prevalence of activating ret protooncogene rearrangements, in thyroid tumors from patients who had received external radiation. Oncogene 199715 1263-1273.
12 Elisei R, Romei C, Vorontsova T, Cosci B, Veremeychik V, Kuchinskaya E et al. RET/PTC rearrangements in thyroid nodules: studies in irradiated and not irradiated, malignant and benign thyroid lesions in children and adults. Journal of Clinical Endocrinology and Metabolism 200186 3211-3216.

13 Bongarzone I, Vigneri P, Mariani L, Collini P, Pilotti S \& Pierotti MA. RET/NTRK1 rearrangements in thyroid gland tumors of the papillary carcinoma family: correlation with clinicopathological features. Clinical Cancer Research 19984 223-228.

14 Learoyd DL, Messina M, Zedenius J, Guinea AI, Delbridge LW \& Robinson BG. RET/PTC and RET tyrosine kinase expression in adult papillary thyroid carcinomas. Journal of Clinical Endocrinology and Metabolism $1998 \mathbf{8 3} 3631-3635$.

15 Mayr B, Potter E, Goretzki P, Ruschoff J, Dietmaier W, Hoang-Vu C et al. Expression of Ret/PTC1, -2, -3, -delta3 and -4 in German papillary thyroid carcinoma. British Journal of Cancer 199877 903-906.

16 Kitamura Y, Minobe K, Nakata T, Shimizu K, Tanaka S, Fujimori $\mathrm{M}$ et al. Ret/PTC3 is the most frequent form of gene rearrangement in papillary thyroid carcinomas in Japan. Journal of Human Genetics 199944 96-102.

17 Musholt TJ, Musholt PB, Khaladj N, Schulz D, Scheumann GF \& Klempnauer J. Prognostic significance of RET and NTRK1 rearrangements in sporadic papillary thyroid carcinoma. Surgery 2000128 984-993.

18 Sugg SL, Ezzat S, Rosen IB, Freeman JL \& Asa SL. Distinct multiple RET/PTC gene rearrangements in multifocal papillary thyroid neoplasia. Journal of Clinical Endocrinology and Metabolism 1998 $834116-4122$.

19 Tallini G, Santoro M, Helie M, Carlomagno F, Salvatore G, Chiappetta $\mathrm{G}$ et al. RET/PTC oncogene activation defines a subset of papillary thyroid carcinomas lacking evidence of progression to poorly differentiated or undifferentiated tumor phenotypes. Clinical Cancer Research 19984 287-294.

20 Fenton CL, Lukes Y, Nicholson D, Dinauer CA, Francis GL \& Tuttle $\mathrm{RM}$. The ret/PTC mutations are common in sporadic papillary thyroid carcinoma of children and young adults. Journal of Clinical Endocrinology and Metabolism 200085 1170-1175.

21 Chua EL, Wu WM, Tran KT, McCarthy SW, Lauer CS, Dubourdieu $\mathrm{D}$ et al. Prevalence and distribution of ret/ptc 1,2, and 3 in papillary thyroid carcinoma in New Caledonia and Australia. Journal of Clinical Endocrinology and Metabolism 200085 2733-2739.

22 Park KY, Koh JM, Kim YI, Park HJ, Gong G, Hong SJ et al. Prevalences of Gs alpha, ras, p53 mutations and ret/PTC rearrangement in differentiated thyroid tumours in a Korean population. Clinical Endocrinology 199849 317-323.

23 Chung JH, Hahm JR, Min YK, Lee MS, Lee MK, Kim KW et al. Detection of RET/PTC oncogene rearrangements in Korean papillary thyroid carcinomas. Thyroid 19999 1237-1243.

24 Motomura T, Nikiforov YE, Namba H, Ashizawa K, Nagataki S, Yamashita $\mathrm{S}$ et al. RET rearrangements in Japanese pediatric and adult papillary thyroid cancers. Thyroid $1998 \mathbf{8} 485-489$.

25 Lee CH, Hsu LS, Chi CW, Chen GD, Yang AH \& Chen JY. High frequency of rearrangement of the RET protooncogene (RET/PTC) in Chinese papillary thyroid carcinomas. Journal of Clinical Endocrinology and Metabolism 199883 1629-1632.

26 La Perle KM, Jhiang SM \& Capen CC. Loss of p53 promotes anaplasia and local invasion in ret/PTC1-induced thyroid carcinomas. American Journal of Pathology 2000157 671-677.

27 Lam KY, Lo CY, Chan KW \& Wan KY. Insular and anaplastic carcinoma of the thyroid: a 45-year comparative study at a single institution and a review of the significance of p53 and p21. Annals of Surgery $2000231329-338$.

Received 29 May 2002

Accepted 29 August 2002 